\title{
The Effect of Spraying Rocket Plant Extract and Ground Addition of Organic Nutrient (Karma maxi org) on The Growth and Production of Cabbage
}

\author{
Ahlam A. Hussein \\ Assistant Professor \\ Dept. of Horticulture - College of Agriculture - University of Diyala \\ Happy_times2053@yahoo.com
}

\begin{abstract}
The experiment was carried out in open field of the research station at College of Agriculture / University of Diyala during two seasons 2018 and 2019. The aim of the study is to investigate the effect of foliar spraying with water extract of Rocket at three concentrations of 0,50 , and $100 \%$ in and ground addition of Organic solution at three concentrations $0,15,20 \mathrm{ml} . \mathrm{L}^{-1}$ in. The Randomized Complete Block Design was used with three replicates. The results showed that spraying water extract of Rocket was superior in $100 \%$. It was found that the highest values in stem height, number of external leaves, head diameter and head weight, and total yield for both seasons $13.36 \mathrm{~cm}, 12.57$ leaf, $14.94 \mathrm{~cm}$, $1.302 \mathrm{~kg}$. plant ${ }^{-1}$ and 43.417 tons. $\mathrm{H}^{-1}$ For the first season, $10.92 \mathrm{~cm}, 12.64$ leaves, $15.26 \mathrm{~cm}$, $1.308 \mathrm{~kg}$. Plant ${ }^{-1}$ and 43.618 tons. $\mathrm{H}^{-1}$ ) for the second season. Also, the ground addition of solution was superior at $20 \mathrm{ml} . \mathrm{L}^{-1}$ in all studied traits. They did not differ significantly from the $15 \mathrm{ml} . \mathrm{L}^{-1}$ concentration. However, they differ significantly from the control treatment, which gave the lowest values for all traits and both seasons. As for the treatment of interaction which was $\left(20 \mathrm{ml} . \mathrm{L}^{-1}\right.$ and $100 \%$ of Rocket extract), it exceeded all treatments and for both seasons.were recorded $13.42 \mathrm{~cm}, 12.88$ leaf, $15.77 \mathrm{~cm}, 1.351 \mathrm{~kg}$. Plant ${ }^{-1}$ and 45.028 tons. $\mathrm{H}^{-1}$ for the first season, as well as $11.03 \mathrm{~cm}, 13.01$ leaf, $15.80 \mathrm{~cm}, 1.383 \mathrm{~kg}$. plant ${ }^{-1}$ and 46.096 tons. $\mathrm{H}^{-1}$ for the second season.
\end{abstract}

Keywords: Nutrient Solution, cabbage, plant extract, open field.

\section{Introduction}

Brassica oleracea var. capitata L. is one of the main winter vegetables in Iraq. It belongs to the cruciferae family and is a useful vegetable (Jim and Tony, 2006). The parts that are eaten are the heads that contain several fresh wrapped leaves, which are used in pickles or cooked. The 100 gm of leaves contain 94\% water, 14 calories, 1 g protein, 2 g carbohydrates, and also contain volatile sulfur materials (Chatterjee et al., 2014). Three types of cabbage produce heads: red, white, and wrinkled. The first and second types are the most common in the world (Matlob et al, 1989). Cabbage is grown in Iraq in the open field, as the total

Dates:

Received: 18 March 2021 
cultivated area for the year 2018 reached about 829.7 Hectares, with a production rate of 6.130 tons. $\mathrm{H}^{-1}$ (Central Statistical Organization, 2018).

It is noticeable that the productivity of cabbage in Iraq has decreased compared to previous years. The cultivated area for 2017 reached 2.670 hectares and a production rate of 7.196 tons. $\mathrm{H}^{-1}$ (Central Statistical Organization, 2017). Therefore, it is necessary to work on increasing the productivity of the cabbage crop by studying all environmental and genetic factors that positively affect the quantity and quality of the crop, and due to the great interest in preserving the environment and improving productivity.

The researchers found that there are many plants that, if extracted and sprayed on parts or the soil, may reduce the infection of some bacterial, fungal, and viral diseases. Therefore, it would improve most of the vegetative and productive traits of most crops (Fayyad, 2005). This is consistent with what Al-Obaidi (2012) found when using water extracts of (Portulaca oleraceae, Malva parviflora, Opinuta ficus indica) plants and spraying them on three varieties of tomatoes. The treatment of spraying with Malva parviflora extract showed significant superiority of all productive characteristics of tomato variety, Sweaty variety in greenhouses. Also spraying with Malva parviflora, extract on eggplant yield resulted from a noticeable superiority in most of the characteristics of vegetative growth and production (Allawi et al., 2017).

Using of nutrients from the organic origin is the basis that must be put in place to raise the production value of agricultural land and reduce environmental pollution resulting from the use of chemical fertilizers (Al-Khafagy, 2010). It is also one of the agricultural methods that complement the process of soil fertilization and is not a substitute for it to provide the plant with the necessary elements where it is not ready in the soil because washing or fixing, which is reflected the increase in vegetative growth. The soil of Iraq is an alkaline soil that stabilizes a lot of nutrients and thus not being ready for absorption by the plant. Therefore, spraying is a suitable way to supply the plant with nutrients that contribute significantly to increasing production and improving its quality. Spraying with organic nutrient at a concentration of $1 \mathrm{ml} / \mathrm{L}^{-1}$ and wheat peat extract with a concentration of $2 \mathrm{ml} / \mathrm{L}^{-1}$ on red cabbage resulted from a significant increase in the characteristics of vegetative growth and the result of plant height, number of external leaves, thickness, and neck of the leaf, leaf area, diameter, head weight, early and total yield (Al-Zaidi and Al-Obaidi, 2017). Al-Shammary (2015) found that the sweet pepper plants treated with the organic nutrient ALGA CEFO 3000 were superior to the characteristics of the plant yield, total yield, fruit weight, total soluble content, and vitamin. C. Husein (2016) indicated that using the liquid mineral feed 
fosfital calcium at a concentration of 3 and $6 \mathrm{ml} / \mathrm{L}^{-1}$ and foliar spray with seaweed extract Algaton-20 in concentrations 2 and $4 \mathrm{ml} / \mathrm{L}^{-1}$ and water extract of dry bean seeds in two concentrations 2.5 and $5 \mathrm{~g} / \mathrm{L}^{-1}$ on cauliflower. When spraying dry bean seeds with the water extract at a concentration of $5 \mathrm{~g} / \mathrm{L}^{-1}$, it recorded the highest leaf area of the plant, while the same extract was given at a concentration of $2.5 \mathrm{~g} / \mathrm{L}^{-1}$ the highest dry weight of the vegetative group and the highest weight of the curd was $0.662 \mathrm{~kg} /$ plant $^{-1}$ compared to the control treatment. While spraying with extract Algaton-20 at a concentration of $2 \mathrm{ml} / \mathrm{L}^{-1}$ the highest number of leaves. Also, spraying times and the concentrations of micronite 35 and their interaction had a significant effect on all the characteristics of pepper. The interaction of three sprays with $3 \mathrm{~cm}^{3} / \mathrm{L}^{-1}$ of micronite 35 gave the highest average of plant height $103.12 \mathrm{~cm}$, branches number 11.61, leaves number 107.41, leaf area $121.31 \mathrm{dc}^{2}$, flowers number 80.96 , and set of flowers percentage 92.403 (Jaffar, 2017).

Because the productivity of cabbage in Iraq is constantly declining in terms of cultivated areas and productivity, the research aims to find ways to raise productivity through the use of natural plant extracts at a low cost and addition of the plant nutrient Karma maxi org and note the effects of these treatments can have on obtaining results that may contribute to raising the productivity of this economic crop in Iraq.

\section{Materials and Methods}

The field that the experiment was carried out in is the research station of the Department of Horticulture College of Agriculture University of Diyala, during two years of the autumn season (2018 and 2019). The soil was prepared by conducting the operations of tillage, smoothing, leveling and divided into three terraces with a length of $20 \mathrm{~m}$ and a width of $75 \mathrm{~cm}$. Drip irrigation pipes were extended along the cultivation lines and the distance between plants was $40 \mathrm{~cm}$. Samples of soil from different areas with a depth of $30 \mathrm{~cm}$ were taken and analyzed at the laboratory. Table (1) shows the physical and chemical properties of the experimental soil. The seeds of Cabbage variety Globe Master produced by the Japanese company (Taki Company) were planted in the dishes of the seedlings with 209 eyes on 10/9/2019 for both seasons in the special place to produce the seedlings of Cabbage. All the conditions were provided for the production of Cabbage seedlings. The seedlings were transplanted to the field on 15/10/2018 for both seasons, as the seedlings were planted on the terraces. Recommended processing for planting including irrigation, weed control, insect and fungal infections control, and crop harvesting were provided until the end of the season, and equally for all experimental units. 


\section{Experimental Factors}

The experiment included two factors: The first three concentrations of nutrient solution (Karma maxi org): Control $\left(\mathrm{H}_{0}\right), 15 \mathrm{ml} / \mathrm{L}^{-1}\left(\mathrm{H}_{1}\right)$, and $20 \mathrm{ml} / \mathrm{L}^{-1}\left(\mathrm{H}_{2}\right)$. The second factor was represented by Rocket extract with two concentrations of 50( $\left.E_{1}\right)$ and $100 \%\left(E_{2}\right)$ in addition to Control treatment $\left(\mathrm{E}_{0}\right)$. The experiment was designed for two seasons as Randomized Complete Block Design with three replicates as a factorial experiment $(3 \times 3)$ into 9 treatments and 27 units (each experimental unit involved 10 plants). The measurements were made for five randomized plants from each unit. The statistical analysis of the studied traits was performed using the SAS program and Duncan Multiplicity test at a 0.05 probability level (AL-raawi and Khalaf Allah, 2000). Karma maxi org nutrient solution was added as a solution to the soil. Table (2) shows the chemical composition of the plant nutrient in the experiment. Plants were treated three times in each growing season, the first after one-month of planting and the second after 15 days, and the third after 15 days after the second treatment. As for the water extract of Rocket, it was sprayed on leaves. The water extract of Rocket was prepared by cutting whole plants before entering the flowering stage, with a length of $(1-1.5 \mathrm{~cm})$ and submerged in water in a ratio of (1: 5) in barrels (200 liters). Then it was filtered by muslin cloth (Awni, 2007 and Fakih, 2010) and sprayed on the plants with two concentrations, the first $50 \%$ after dilution with water by $(50 \%)$, and the second by $(100 \%)$ without dilution, and at a rate of sprinkling every (15 days) starting from the date of the seedling, until the end of the agricultural season and for two seasons.

Table 1. Physical and chemical properties of the soil before planting

\begin{tabular}{|c|c|c|}
\hline Trait & Value & Unit \\
\hline Organic Matter & 1.19 & $\%$ \\
\hline $\mathrm{CaCO}_{3}$ & 207.10 & $\mathrm{~g} \mathrm{~kg}^{-1}$ \\
\hline $\mathrm{EC}(1: 1)$ & 6.58 & $\mathrm{dsm}^{-1}$ \\
\hline $\mathrm{Ph}(1: 1)$ & 7.82 & \\
\hline \multicolumn{3}{|c|}{ Elements availability } \\
\hline Nitrogen & 10.05 & $\mathrm{Mg} \mathrm{kg}^{-1}$ \\
\hline Phosphorus & 7.241 & $\mathrm{Mg} \mathrm{kg}^{-1}$ \\
\hline Potassium & 199.81 & $\mathrm{Mg} \mathrm{kg}^{-1}$ \\
\hline Soil Particle Size & 216 & $\mathrm{~g} \mathrm{~kg}^{-1}$ \\
\hline Clay & 232 & $\mathrm{~g} \mathrm{~kg}^{-1}$ \\
\hline Silt & 552 & $\mathrm{~g} \mathrm{~kg}^{-1}$ \\
\hline Sand & Sandy loam & \\
\hline Texture Class & & \\
\hline
\end{tabular}


Table 2. Chemical composition of the plant nutrient used in the experiment

\begin{tabular}{|l|c|}
\hline \multicolumn{1}{|c|}{ Karma maxi org } & $\mathbf{\%}(\mathbf{w} / \mathbf{v})$ \\
\hline Humic acid & 10 \\
\hline Fulvic acid & 2 \\
\hline Amino acid & 4 \\
\hline Potassium(K2O) & 3 \\
\hline Nitrogen (N) & 4 \\
\hline Organic Matter & 20 \\
\hline Density (g/L) & 1.1 \\
\hline
\end{tabular}

\section{Study Indicators}

Stem height $(\mathrm{cm})$ the height was measured from the stem's contact area with the soil to the head's contact area by metric tape.

Number of external leaves (leaf Plant ${ }^{-1}$ ) the number of external leaves (unwrapped) for each plant of the selected plants was calculated and then the average was calculated.

Head diameter $(\mathbf{c m})$ : The head diameter of each experimental unit was measured by the Verna.

Head weight (kg): The head weight of all experimental units was obtained by the digital scale.

Total yield (for heads without external leaves) $\left(\right.$ ton. $\mathbf{H}^{-1}$ ): The total yield of cabbage heads that included the marketing heads from the yield of the experimental units for the heads.

\section{Results and Discussion}

\section{1-Stem Height:}

Table (3) shows the first season the superiority of spray treatment with water extract of Rocket $\mathrm{E}_{2}$ by giving the highest height of the plant reached to $13.36 \mathrm{~cm}$, as it did not differ significantly from the treatment of spraying $E_{1}$, which exceeded the control treatment. The latter gave the lowest rate which was $11.92 \mathrm{~cm}$. The treatments of $\mathrm{H}_{1}$ and $\mathrm{H}_{2}$ were superior by giving the highest plant height $(12.88$ and $13.03 \mathrm{~cm})$ respectively. They did not differ significantly from each other. The interaction treatment $\mathrm{E}_{2} \mathrm{H}_{2}$ recorded the highest rate of this trait of $13.42 \mathrm{~cm}$ compared to the control treatment that gave the lowest height of the plant $(11.16 \mathrm{~cm})$. In the same table for the second season, spraying the water extract of Rocket with a concentration of $100 \%\left(\mathrm{E}_{2}\right)$ gave the highest height of the plant reached to $10.92 \mathrm{~cm}$ and did not differ significantly from treatment $E_{1}$ as they exceeded the control treatment which gave the lowest height of the plant reached $9.21 \mathrm{~cm}$. As for the ground addition 
treatments of the nutrient solution, both the $\mathrm{H}_{1}$ and $\mathrm{H}_{2}$ are superior to this trait, as the height reached 10.28 and $10.39 \mathrm{~cm}$, respectively. As for the interaction the superiority of the $\mathrm{E}_{2} \mathrm{H}_{2}$ and $\mathrm{E}_{2} \mathrm{H}_{1}$ interaction treatment, gave the highest plant height of $(11.03$ and $11.00 \mathrm{~cm})$, thus the best compared with the other of the treatments, including the control treatment which gave the lowest height of $9.06 \mathrm{~cm}$.

Table 3. Effect of foliar spraying and ground addition of organic nutrient and their interaction on the plant height $\left(\mathrm{cm} / \text { plant }^{-1}\right)^{*}$

First season 2018

\begin{tabular}{|c|c|c|c|c|}
\hline \multirow{2}{*}{$\begin{array}{c}\text { Karma maxi org } \\
\mathrm{ml}^{-1} \mathrm{~L}^{-1}\end{array}$} & \multicolumn{3}{|c|}{ Water extract of Eruca sativa $\mathbf{\%})$} & \multirow{2}{*}{$\begin{array}{c}\text { Average of } \\
\text { Karma maxi org }\end{array}$} \\
\cline { 2 - 4 } $\mathbf{H}_{\mathbf{0}}$ & $\mathbf{E}_{\mathbf{0}}$ & $\mathbf{E}_{\mathbf{1}}$ & $\mathbf{E}_{\mathbf{2}}$ & \\
\hline $\mathbf{H}_{\mathbf{1}}$ & $11.16 \mathrm{~d}$ & $13.31 \mathrm{a}$ & $13.37 \mathrm{a}$ & $12.61 \mathrm{~B}$ \\
\hline $\mathbf{H}_{\mathbf{2}}$ & $12.28 \mathrm{c}$ & $13.08 \mathrm{~b}$ & $13.30 \mathrm{ab}$ & $12.88 \mathrm{AB}$ \\
\hline $\begin{array}{c}\text { Average of water extract } \\
\text { of Eruca sativa }\end{array}$ & $12.33 \mathrm{c}$ & $13.36 \mathrm{a}$ & $13.42 \mathrm{a}$ & $13.03 \mathrm{~A}$ \\
\hline
\end{tabular}

Second season 2019

\begin{tabular}{|c|c|c|c|c|}
\hline \multirow{2}{*}{$\begin{array}{c}\text { Karma maxi org } \\
\mathrm{ml.L}^{-1}\end{array}$} & \multicolumn{2}{|c|}{ Water extract of Eruca sativa( \%) } & \multirow{2}{*}{$\begin{array}{c}\text { Average of } \\
\text { Karma maxi org }\end{array}$} \\
\cline { 2 - 4 } $\mathbf{H}_{\mathbf{0}}$ & $\mathbf{E}_{\mathbf{0}}$ & $\mathbf{E}_{\mathbf{1}}$ & $\mathbf{E}_{\mathbf{2}}$ & \\
\hline $\mathbf{H}_{\mathbf{1}}$ & $9.06 \mathrm{e}$ & $10.68 \mathrm{bc}$ & $10.75 \mathrm{~b}$ & $10.16 \mathrm{~B}$ \\
\hline $\mathbf{H}_{\mathbf{2}}$ & $9.24 \mathrm{~d}$ & $10.62 \mathrm{c}$ & $11.00 \mathrm{a}$ & $10.28 \mathrm{AB}$ \\
\hline $\begin{array}{c}\text { Average of water extract } \\
\text { of Eruca sativa }\end{array}$ & $9.33 \mathrm{~d}$ & $10.82 \mathrm{ab}$ & $11.03 \mathrm{a}$ & $10.39 \mathrm{~A}$ \\
\hline
\end{tabular}

The values of similar letters are not significantly different from each other according to the Duncan test below the $5 \%$ *

\section{Number of external leaves (leaf/Plant $\left.{ }^{-1}\right)$ :}

The results of the first and second seasons in the table (4) indicate that there were no significant differences between the two treatments of water extract of Rocket $E_{1}$ and $E_{2}$ in the number of external leaves of the cabbage plant. The number of leaves for each of them was 12.42 and 12.57 plant leaves $^{-1}$ for the first season, 12.62 and 12.64 plant leaves $^{-1}$ for the second season. However, they outperformed the control treatment that gave the lowest number of external leaves12.22 and 12.26 leaf $^{-1}$ plant for the first and second seasons respectively. $\mathrm{H}_{1}$ and $\mathrm{H}_{2}$ spraying treatments were not significantly different from each other of this trait and for the two seasons, but they outperformed the control treatment, as the number of leaves reached 12.50 leaf/Plant ${ }^{-1}$ each for them to the first season and 12.49 and 12.59 leave Plant ${ }^{-1}$ for the second season. While the control sample recorded 12.21 and 12.43 leaf ${ }^{-1}$ for both seasons. As for the interaction treatment was superior to $\mathrm{E}_{2} \mathrm{H}_{2}$ and for the two seasons by giving the highest number of leaves of 12.88 and 13.01 leaf/Plant ${ }^{-1}$. The results indicated the superiority of the ground addition with the $\mathrm{H}_{1}$ and $\mathrm{H}_{2}$ concentrations in these two characteristics compared to the control treatment, with regard to interaction, the higher 
concentration of the extract $E_{2}$ outperformed with the higher concentration of the nutrient solution $\mathrm{H}_{2}$ in giving the best results. The reason for the cabbage response may be due to the higher concentration of both the water extract and the ground addition of the nutrient solution as a stressful crop of the soil and need a lot of nutrients necessary for growth. Both the extract and the nutrient solution were able to provide the needs of the plant from these elements that led to giving the best vegetative growth. These results are consistent with what Al-Lamy et.al (2018) on the cabbage plant.

Table 4. Effect of foliar spraying and ground addition of organic nutrient and their interaction on the number of external leaves (leaf/plant $\left.{ }^{-1}\right)^{*}$

First season 2018

\begin{tabular}{|c|c|c|c|c|}
\hline \multirow{2}{*}{$\begin{array}{c}\text { Karma maxi org } \\
\mathrm{ml}^{-1} \mathrm{~L}^{-1}\end{array}$} & \multicolumn{2}{|c|}{ Water extract of Eruca sativa $\mathbf{\%})$} & $\begin{array}{c}\text { Average of } \\
\text { Karma maxi org }\end{array}$ \\
\cline { 2 - 4 } & $\mathbf{E}_{\mathbf{0}}$ & $\mathbf{E}_{\mathbf{1}}$ & $\mathbf{E}_{\mathbf{2}}$ & \\
\hline $\mathbf{H}_{\mathbf{0}}$ & $11.80 \mathrm{e}$ & $12.44 \mathrm{bc}$ & $12.40 \mathrm{c}$ & $12.21 \mathrm{~B}$ \\
\hline $\mathbf{H}_{\mathbf{1}}$ & $12.65 \mathrm{~b}$ & $12.43 \mathrm{c}$ & $12.44 \mathrm{bc}$ & $12.50 \mathrm{~A}$ \\
\hline $\mathbf{H}_{\mathbf{2}}$ & $12.22 \mathrm{~d}$ & $12.40 \mathrm{c}$ & $12.88 \mathrm{a}$ & $12.50 \mathrm{~A}$ \\
\hline $\begin{array}{c}\text { Average of water extract } \\
\text { of Eruca sativa }\end{array}$ & 12.22 & 12.42 & 12.57 & \\
\hline
\end{tabular}

Second season 2019

\begin{tabular}{|c|c|c|c|c|}
\hline \multirow{2}{*}{$\underset{\mathrm{ml} . \mathrm{L}^{-1}}{\text { Karma maxi org }}$} & \multicolumn{3}{|c|}{ Water extract of Eruca sativa (\%) } & \multirow{2}{*}{$\begin{array}{c}\text { Average of } \\
\text { Karma maxi org }\end{array}$} \\
\hline & $\mathbf{E}_{\mathbf{0}}$ & $\mathbf{E}_{1}$ & $\mathbf{E}_{2}$ & \\
\hline $\mathbf{H}_{0}$ & $12.10 \mathrm{~d}$ & $12.77 \mathrm{ab}$ & $12.43 \mathrm{c}$ & $12.43 \mathrm{~B}$ \\
\hline $\mathrm{H}_{1}$ & $12.44 \mathrm{c}$ & $12.53 \mathrm{bc}$ & $12.50 \mathrm{bc}$ & $12.49 \mathrm{AB}$ \\
\hline $\mathbf{H}_{2}$ & $12.26 \mathrm{c}$ & $12.50 \mathrm{bc}$ & $13.01 \mathrm{a}$ & $12.59 \mathrm{~A}$ \\
\hline $\begin{array}{l}\text { Average of water extract } \\
\text { of Eruca sativa }\end{array}$ & $\begin{array}{c}12.26 \\
\mathrm{~B}\end{array}$ & $\begin{array}{c}12.62 \\
\mathrm{~A}\end{array}$ & $\begin{array}{c}12.64 \\
\mathrm{~A}\end{array}$ & \\
\hline
\end{tabular}

The values of similar letters are not significantly different from each other according to the Duncan test below the $5 \%$ *

\section{Head diameter (cm):}

The results in table 5 indicate the superiority of the treatment of spraying the water extract of Rocket $\left(\mathrm{E}_{2}\right)$ over the other of the spraying treatments and for both seasons of cultivation in the characteristic head diameter reached 14.49 and $15.26 \mathrm{~cm}$ respectively. The spraying treatments $\mathrm{H}_{1}$ and $\mathrm{H}_{2}$ did not differ from each other significantly in this trait for both seasons $(15.07$ and $15.21 \mathrm{~cm})$, but they outperformed the control treatment that gave the lowest head diameter of 13.42 and $14.21 \mathrm{~cm}$, respectively, for both seasons. The interaction treatments, $\mathrm{E}_{2} \mathrm{H}_{2}$, and the two seasons were treated by giving the largest head diameter of 15.77 and 15.80 $\mathrm{cm}$, respectively, outperforming all the treatments, including the control that achieved the lowest head diameter for both seasons. 
Table 5. Effect of foliar spraying and ground addition of organic nutrient and their interaction on the head diameter $(\mathrm{cm}) *$

First season 2018

\begin{tabular}{|c|c|c|c|c|}
\hline \multirow{2}{*}{$\begin{array}{c}\text { Karma maxi org } \\
\mathrm{ml}^{-1}\end{array}$} & \multicolumn{2}{|c|}{ Water extract of Eruca sativa $\mathbf{\%})$} & $\begin{array}{c}\text { Average of } \\
\text { Karma maxi org }\end{array}$ \\
\cline { 2 - 4 } $\mathbf{H}_{\mathbf{0}}$ & $\mathbf{E}_{\mathbf{0}}$ & $\mathbf{E}_{\mathbf{1}}$ & $\mathbf{E}_{\mathbf{2}}$ & $13.42 \mathrm{~B}$ \\
\hline $\mathbf{H}_{\mathbf{1}}$ & $13.00 \mathrm{e}$ & $13.50 \mathrm{~d}$ & $13.78 \mathrm{~d}$ & $14.81 \mathrm{~A}$ \\
\hline $\mathbf{H}_{\mathbf{2}}$ & $14.44 \mathrm{c}$ & $14.72 \mathrm{c}$ & $15.28 \mathrm{~b}$ & $15.07 \mathrm{~A}$ \\
\hline $\begin{array}{c}\text { Average of water extract } \\
\text { of Eruca sativa }\end{array}$ & $14.33 \mathrm{c}$ & $15.11 \mathrm{~b}$ & $15.77 \mathrm{a}$ & \\
\hline
\end{tabular}

Second season 2019

\begin{tabular}{|c|c|c|c|c|}
\hline \multirow{2}{*}{$\begin{array}{c}\text { Karma maxi org } \\
\mathrm{ml.L}^{-1}\end{array}$} & \multicolumn{3}{|c|}{ Water extract of Eruca sativa (\%) } & $\begin{array}{c}\text { Average of } \\
\text { Karma maxi org }\end{array}$ \\
\cline { 2 - 4 } & $\mathbf{E}_{\mathbf{0}}$ & $\mathbf{E}_{\mathbf{1}}$ & $\mathbf{E}_{\mathbf{2}}$ & $14.21 \mathrm{~B}$ \\
\hline $\mathbf{H}_{\mathbf{0}}$ & $13.65 \mathrm{e}$ & $14.33 \mathrm{~d}$ & $14.67 \mathrm{~cd}$ & $15.02 \mathrm{~A}$ \\
\hline $\mathbf{H}_{\mathbf{1}}$ & $14.30 \mathrm{~d}$ & $15.44 \mathrm{~b}$ & $15.33 \mathrm{~b}$ & $15.21 \mathrm{~A}$ \\
\hline $\mathbf{H}_{\mathbf{2}}$ & $14.96 \mathrm{bc}$ & $14.88 \mathrm{c}$ & $15.80 \mathrm{a}$ & \\
\hline $\begin{array}{c}\text { Average of water extract } \\
\text { of Eruca sativa }\end{array}$ & 14.30 & 14.88 & 15.26 & \\
\hline
\end{tabular}

The values of similar letters are not significantly different from each other according to the Duncan test below the $5 \%$ *

\section{4- Head weight (kg):}

The results in table (6) show the superiority of the spraying treatment with water extract of Rocket $\left(\mathrm{E}_{2}\right)$. By giving the highest head weight of $1.302 \mathrm{~kg}$ in the first season it outperformed the other treatments that recorded the lowest head weight $1.163 \mathrm{~kg}$. But this treatment in the second season did not record any significant difference from the treatment of spraying with water extract $\mathrm{E}_{1}$. However, it outperformed the control treatment that recorded the lowest head weight in both seasons of 1.163 and $1.271 \mathrm{~kg}$, respectively. The $\mathrm{H}_{1}$ and $\mathrm{H}_{2}$ spray treatments did not differ significantly from each other in this trait and for the two seasons $(1.237,1.265 \mathrm{~kg}$ for the first season and $1.315,1.295 \mathrm{~kg}$ for the second season) respectively. They exceeded the control treatment that gave the lowest head weight of 1.188 and $1.261 \mathrm{~kg}$, respectively, and for both seasons. The interaction treatments, $\mathrm{E}_{2} \mathrm{H}_{2}$ were superior in both seasons by giving the highest head weight of 1.351 and $1.383 \mathrm{~kg}$, respectively, outperforming all treatments, including the Control that gave the lowest head weight for both seasons. 
Table 6. Effect of foliar spraying and ground addition of organic nutrient and their interaction on the head weight $(\mathbf{k g}) *$

First season 2018

\begin{tabular}{|c|c|c|c|c|}
\hline \multirow{2}{*}{$\begin{array}{c}\text { Karma maxi org } \\
\mathrm{ml.L}^{-1}\end{array}$} & \multicolumn{3}{|c|}{ Water extract of Eruca sativa $\mathbf{( \% )}$} & \multirow{2}{*}{$\begin{array}{c}\text { Average of } \\
\text { Karma maxi org }\end{array}$} \\
\cline { 2 - 4 } & $\mathbf{E}_{\mathbf{0}}$ & $\mathbf{E}_{\mathbf{1}}$ & $\mathbf{E}_{\mathbf{2}}$ & \\
\hline $\mathbf{H}_{\mathbf{0}}$ & $1.125 \mathrm{f}$ & $1.171 \mathrm{e}$ & $1.269 \mathrm{bc}$ & $1.188 \mathrm{~B}$ \\
\hline $\mathbf{H}_{\mathbf{1}}$ & $1.188 \mathrm{e}$ & $1.236 \mathrm{~d}$ & $1.288 \mathrm{~b}$ & $1.237 \mathrm{~A}$ \\
\hline $\mathbf{H}_{\mathbf{2}}$ & $1.178 \mathrm{e}$ & $1.266 \mathrm{c}$ & $1.351 \mathrm{a}$ & $1.265 \mathrm{~A}$ \\
\hline $\begin{array}{c}\text { Average of water extract } \\
\text { of Eruca } \text { sativa }\end{array}$ & 1.163 & 1.224 & 1.302 & \\
\hline
\end{tabular}

Second season 2019

\begin{tabular}{|c|c|c|c|c|}
\hline \multirow{2}{*}{$\begin{array}{c}\text { Karma maxi org } \\
\mathrm{ml}^{-1} \mathrm{~L}^{-1}\end{array}$} & \multicolumn{2}{|c|}{ Water extract of Eruca sativa (\%) } & $\begin{array}{c}\text { Average of } \\
\text { Karma maxi org }\end{array}$ \\
\cline { 2 - 4 } & $\mathbf{E}_{\mathbf{0}}$ & $\mathbf{E}_{\mathbf{1}}$ & $\mathbf{E}_{\mathbf{2}}$ & $1.261 \mathrm{~B}$ \\
\hline $\mathbf{H}_{\mathbf{0}}$ & $1.255 \mathrm{~g}$ & $1.267 \mathrm{ef}$ & $1.263 \mathrm{f}$ & $1.295 \mathrm{~A}$ \\
\hline $\mathbf{H}_{\mathbf{1}}$ & $1.281 \mathrm{~cd}$ & $1.325 \mathrm{~b}$ & $1.280 \mathrm{~cd}$ & $1.315 \mathrm{~A}$ \\
\hline $\mathbf{H}_{\mathbf{2}}$ & $1.277 \mathrm{de}$ & $1.287 \mathrm{c}$ & $1.383 \mathrm{a}$ & \\
\hline $\begin{array}{c}\text { Average of water extract } \\
\text { of Eruca sativa }\end{array}$ & 1.271 & 1.293 & 1.308 & \\
\hline
\end{tabular}

The values of similar letters are not significantly different from each other according to the Duncan test below the $5 \%$

\section{5- Total yield (for heads without external leaves) $\left(\right.$ ton. $\left.\mathbf{H}^{-1}\right)$ :}

The results in table (7) show that the spraying treatment with water extract of Rocket $\left(E_{2}\right)$ was superior by giving the highest total yield of 43.417 tons. $\mathrm{H}^{-1}$ in the first season, outperforming the other treatments that recorded the lowest total yield. However, this treatment in the second season did not record a significant difference from the spray treatment with water extract $\left(\mathrm{E}_{1}\right)$. They outperformed the control treatment that gave the lowest total yield in both seasons. 38.785 and 42.362 tons $/ \mathrm{H}^{-1}$, respectively. About the ground addition of the nutrient solution, we find that the spraying treatments $\mathrm{H}_{1}$ and $\mathrm{H}_{2}$ did not differ from each other significantly in this trait for both seasons, as they exceeded the control treatment that gave the lowest total yield of 39.606 and 42.050 tons $/ \mathrm{H}^{-1}$ respectively for both seasons. The interaction treatment $\mathrm{E}_{2} \mathrm{H}_{2}$ both seasons were superior by giving the highest total yield of 45.028 and 46.096 tons $/ \mathrm{H}^{-1}$, respectively, outperforming all treatments, including the control which gave the lowest total values for both seasons. 
Table 7. The effect of foliar spraying and ground addition of organic nutrient and their interaction on the Total yield (tons/ $\left.\mathbf{H}^{-1}\right)^{*}$

First season 2018

\begin{tabular}{|c|c|c|c|c|}
\hline \multirow{2}{*}{$\begin{array}{c}\text { Karma maxi org } \\
\mathrm{ml}^{-} \mathrm{L}^{-1}\end{array}$} & \multicolumn{3}{|c|}{ Water extract of Eruca sativa $\mathbf{( \% )}$} & \multirow{2}{*}{$\begin{array}{c}\text { Average of } \\
\text { Karma maxi org }\end{array}$} \\
\cline { 2 - 4 } & $\mathbf{E}_{\mathbf{0}}$ & $\mathbf{E}_{\mathbf{1}}$ & $\mathbf{E}_{\mathbf{2}}$ & $\mathrm{B} 39.606$ \\
\hline $\mathbf{H}_{\mathbf{0}}$ & $37.496 \mathrm{f}$ & $39.028 \mathrm{e}$ & $42.296 \mathrm{bc}$ & $\mathrm{A} 41.240$ \\
\hline $\mathbf{H}_{\mathbf{1}}$ & $9.596 \mathrm{e} 3$ & $41.196 \mathrm{~d}$ & $42.928 \mathrm{~b}$ & $\mathrm{~A} 42.162$ \\
\hline $\mathbf{H}_{\mathbf{2}}$ & $39.264 \mathrm{e}$ & $42.196 \mathrm{c}$ & $45.028 \mathrm{a}$ & \\
\hline $\begin{array}{c}\text { Average of water extract } \\
\text { of Eruca sativa }\end{array}$ & 38.785 & 40.806 & 43.417 & \\
\hline
\end{tabular}

Second season 2019

\begin{tabular}{|c|c|c|c|c|}
\hline \multirow{2}{*}{$\begin{array}{c}\text { Karma maxi org } \\
\mathrm{ml}^{-1} \mathrm{~L}^{-1}\end{array}$} & \multicolumn{2}{|c|}{ Water extract of Eruca sativa (\%) } & $\begin{array}{c}\text { Average of } \\
\text { Karma maxi org }\end{array}$ \\
\cline { 2 - 5 } & $\mathbf{E}_{\mathbf{0}}$ & $\mathbf{E}_{\mathbf{1}}$ & $\mathbf{E}_{\mathbf{2}}$ & $\mathrm{B} 42.050$ \\
\hline $\mathbf{H}_{\mathbf{0}}$ & $41.828 \mathrm{~g}$ & $42.228 \mathrm{ef}$ & $42.096 \mathrm{f}$ & $\mathrm{A} 43.172$ \\
\hline $\mathbf{H}_{\mathbf{1}}$ & $42.696 \mathrm{~cd}$ & $44.164 \mathrm{~b}$ & $42.664 \mathrm{~cd}$ & $43.852 \mathrm{~A}$ \\
\hline $\mathbf{H}_{\mathbf{2}}$ & $42.564 \mathrm{de}$ & $42.896 \mathrm{c}$ & $46.096 \mathrm{a}$ & \\
\hline $\begin{array}{c}\text { Average of water extract } \\
\text { of Eruca } \text { sativa }\end{array}$ & 42.362 & 43.096 & 43.618 & \\
\hline
\end{tabular}

The values of similar letters are not significantly different from each other according to the Duncan test below the $5 \%$

The results of the yield and its components represented by the diameter, head, weight of heads, and the total yield in the table $(5,6,7)$ showed the superiority of spraying the water extract of Rocket with a concentration at (100\%) $E_{2}$ for the two seasons, despite the absence of significant differences in some of the characteristics of the yield with spraying at a concentration of $50 \%$ of this extract. The results in all the tables indicated the superiority of the ground addition in the concentrations $\mathrm{H}_{1}$ and $\mathrm{H}_{2}$ in all the product characteristics compared to the control treatment. As for the interaction, the higher concentration of the extract $\mathrm{E}_{2}$ exceeded the higher concentration of the nutrient solution $\mathrm{H}_{2}$ in giving the best results in all the above characteristics. The reason is that these treatments have led to improvement and increase in the vegetative group, which was positively led to giving the highest weight of the heads. Thus was led to give the total yield. These results are consistent with Al-Zaidi and Al-Obaidi (2017) who indicated that spraying with wheat peat extract and Vegeamino organic nutrient on red cabbage gave the best results in all vegetative and productive traits. The interaction treatment gave the highest values for stem length, the number of external leaves, diameter and head weight, early and total yield. Also, this result is consistent with Tohafi et. al. (2010). They found significant increases in the number of fruits, the weight of the fruit, plant yield, and the quantitative yield of pepper plants grown inside greenhouses when treated with Alga600 foliar spray at a level of $0.5 \mathrm{~g}$. $\mathrm{L}^{-1}$ with $0.2 \mathrm{~g}$. $\mathrm{L}^{-1}$ of Wafeer fertilizer. 


\section{Conclusions}

The current study concludes that the higher concentration of water extract Rocket and the nutrient solution was better by giving higher values and improving the vegetative and productive characteristics of cabbage.

\section{Conflict of interest}

The authors declare that they have no conflict interests.

\section{Acknowledgments}

The authors acknowledge the staff of the research station at Department of Horticulture / Colleges of Agriculture / University of Diyala have assisted in field service operations.

\section{References}

AL-khafagy, A. M. H. 2010. Application Effects of Some Organic Fertilizers on Productivity and Quality of Bulbs and Seeds of Onion. M.Sc. Thesis. Horticulture Department. College of Agriculture. University of Baghdad. Iraq.

AL-lamy, K.A.M., M.H. Abeed and M.A.A. Sakr. 2018. Effect of Reef Amirich spraying in growth and yield two cultivars of Cabbage. The Journal of Kerbala for Agricultural Sciences. 5(8):116-123.

Allawi, M. M.,A. A. Hussien and A. R. A. Obed . 2017. Response of eggplant for foliar spray with Malva parvflora extract and inoculation with biofertilizer in green houses. Journal of Agriculture and Veterinary Science.10 (8):35-40.

DOI: $10.9790 / 2380-1008033540$

Al-obaidi, A.A.H., R.Wehbi.,N. Sofan. 2013. Effects of spraying some plant extracts on productivity of tomato planted in plastic houses. The Iraqi Journal of Agricultural Sciences. 44(1): 81-88.

https://iasj.net/iasj/download/d3c5b56846890145

Alrawi, K. M. and K. Allah . 2000. Design and analysis of agricultural experiments. Dar Al Kutub Printing \& Publishing Est, University of Al Mosul, Iraq.

Al-Shammary, A. M. A. 2015. Effect of organic nutrition with foliar spraying in growth and yield for four genotype of sweet pepper Capsicum annuum L. Diyala Agricultural Sciences Journal.7 (1):174-188.

https://www.iasj.net/iasj/download/ea76d9116a6cb8e5 
Al-zaidi, A . K .N and R . M . AL-Obaidi. 2017. Effect of adding wheat peat and spraying with its extract and organic nutrient vegeamino on growth and yield of red cabbage. The Iraqi Journal of Agricultural Sciences. 48 (2):429-438.

DOI: https://doi.org/10.36103/ijas.v48i2.405

Aoni, H. 2007. Fertilization and soil. www.forum.zira3.net

Central Statistical Organization. 2017. Annual statistical group. The Ministry of Planning. Iraq.

CentralStatistical Organization. 2018. Annual statistical group. The Ministry of Planning. Iraq

Chatterjee,R., S. Bandhopadhyay and J.C. Jana . 2014. Organic Amendments Influencing Growth, head yield and Nitrogenuse efficiency in cabbage (Brassica oleracea var.capitata L.).Pundibari Cooch Beharindia:148-153.

http://iasir.net/AIJRFANSpapers/AIJRFANS14-153.pdf

Faqih,. R. 2010. How to Prepare the Organic Fertilization. Article, No. 223. www.baqiatollh.net.

Fayyad,M.H. 2005. Effect of Spraying Some Growth Regulators and Plant Extracts on Growth and Yield of Snake Cucumber(Cucumis melo var . flexuoses Naud) and Cucumber (Cucumis sativus L.) Plants. Ph. D. thesis, University of Basrah, Iraq.

Husein, M.A. 2016.Response of Cauliflower Plants to Spray With Nutrients Solutions From Different Sources. The Iraqi Journal of Agricultural Science. 47(5):1218-1224. https://jcoagri.uobaghdad.edu.iq/index.php/intro/article/view/499

Jaffar, S.A. 2017. Effect of sprays number and foliar micronite 35 on growth and yield of pepper under un heated greenhouse. The Iraqi Journal of Agricultural Sciences. 48(1):248-255.

https://search.proquest.com/openview/2c23be373c5a250977c9eae6e23e3463/1?pqorigsite $=$ gscholar $\&$ cbl $=2045989$

Jim, M. and N.Tony, 2006. Cabbage growing prime fact 90. Replaces Gfact.H8.1.27. NSW Department of primary Industries: 1-7. https://fliphtm15.com/tzck/xzbk/basic. Jule 2006.

Matlob, A. N.,A. Sultan, and K.S.Abdoole.1989. Production of Vegetables. Second Edition . Ministry of Higher Education and Scientific Research. Iraq. 255p.

Tohafi, S.A., A. S. hassan and A. R. Karem.2010. Effect of Sprays and Foliar Fertilization on Growth and Yield of Pepper Plant (Capsicum annuиm L.) Under Plastic House Conditions. The Iraqi Journal of Science 15 (1):40- 47. 